\title{
MAINTENANCE OF SPERMATOGENESIS WITH TESTOSTERONE OR DIHYDROTESTOSTERONE IN HYPOPHYSECTOMIZED RATS
}

\author{
NAZIR AHMAD, GARY G. HALTMEYER* \\ AND KRISTEN B. EIK-NES \\ Departments of Anatomy and Physiology, University of Southern California, \\ School of Medicine, Los Angeles, California 90033, U.S.A., and \\ Institute of Biophysics, University of Trondheim, \\ Trondheim 7000, Norway
}

(Received 18th October 1974)

In an earlier study (Ahmad, Haltmeyer \& Eik-Nes, 1973), we reported maintenance of spermatogenesis in tubules of hypophysectomized rats adjoining intratesticular implants of silastic capsules containing testosterone or dihydrotestosterone (DHT). It was suggested that the local differences in the testes of the rats receiving the two treatments might be attributed to the relative amounts of hormone escaping from the silastic capsules. It was calculated that only $8.3 \mu \mathrm{g} \mathrm{DHT} /$ day escaped from the capsule over the course of the experiment compared to $12 \cdot 0 \mu \mathrm{g}$ testosterone/day.

In order to compare the maintenance of spermatogenesis in DHT- and testosterone-treated rats with that in normal controls, experiments were undertaken in which larger quantities of hormones than those in the previous study were administered to hypophysectomized rats.

Twenty-eight male Long-Evans rats were hypophysectomized at 90 days of age by the parapharyngeal approach and were randomly assigned to one of three treatment groups. Treatment was initiated immediately after hypophysectomy and consisted of daily subcutaneous injections of $1 \mathrm{mg} \mathrm{DHT}$ (Group 1) or $1 \mathrm{mg}$ testosterone (Group 2) dissolved in $0.1 \mathrm{ml}$ corn oil. Hypophysectomized controls were given $0.1 \mathrm{ml}$ corn oil daily (Group 3). Six untreated intact rats (Group 4) completed the experimental design. The animals were housed at $35^{\circ} \mathrm{C}$ in a lightcontrolled room ( $14 \mathrm{hr}$ dark $/ 10 \mathrm{hr}$ light) and were allowed free access to Purina Lab Chow and water.

In order to ascertain any effects on mating behaviour as well as the capacity of spermatozoa from animals in Groups 1 and 2 to fertilize, a nulliparous Sprague-Dawley female was placed with each male for the last week of the study (Days 22 to 28 ). The females were kept under observation to term and the number of young born was recorded.

After 4 weeks of treatment, the males were killed; ventral prostates, seminal vesicles and testes were dissected free, weighed and placed in Bouin's solution. The head of the epididymis was cut and a smear was made on a slide and examined under a microscope for the presence of motile spermatozoa. All of the

\footnotetext{
* Deceased.
} 
tissues were prepared for histological examination as described earlier (Ahmad et al., 1973).

In the present study, the maintenance of spermatogenesis was assessed by counting the tubules at specific stages of spermatogenesis (Leblond \& Clermont, 1952a; Clermont \& Perey, 1957). Identification of the various steps of spermatid development and the stages of seminiferous epithelial cycle was based on the system of classification proposed by Leblond \& Clermont (1952b). Only those tubules showing an entire cellular association comparable to that in intact rats were considered to have been maintained. Other tubules which showed total disruption of cellular association or incomplete association were considered to be regressing. In a given cross-section of testis, the total number of tubules, the tubules at stages VII and VIII, and the regressing tubules were counted for quantification of spermatogenesis. At the magnification at which the tubules were counted, it was difficult to distinguish between stages VII and VIII and the two were therefore combined.

Table 1. Body weight change and paired organ weights of intact and hypophysectomized rats treated with DHT, testosterone or oil

\begin{tabular}{|c|c|c|c|c|c|c|c|c|}
\hline \multirow{2}{*}{ Group } & \multirow{2}{*}{ Treatment } & \multirow{2}{*}{$\begin{array}{c}\text { No. } \\
\text { of } \\
\text { rats }\end{array}$} & \multicolumn{2}{|c|}{ Body weight $(g)$} & \multirow{2}{*}{$\begin{array}{c}\% \\
\text { Change }\end{array}$} & \multirow{2}{*}{$\begin{array}{c}\text { Wt of } \\
\text { testes } \\
(\mathrm{g})\end{array}$} & \multirow{2}{*}{$\begin{array}{c}\text { Ventral } \\
\text { prostate } \\
\text { wt }(\mathrm{g})\end{array}$} & \multirow{2}{*}{$\begin{array}{c}\text { Seminal } \\
\text { vesicle } \\
\text { wt }(g)\end{array}$} \\
\hline & & & Initial & Final & & & & \\
\hline 1 & $\mathrm{DH}^{\prime}$ & 10 & 336 & 279 & -17 & $2 \cdot 40^{\mathrm{b}}$ & $0.70^{\mathrm{b}}$ & $2 \cdot 07^{b}$ \\
\hline 2 & Testosterone & 9 & 338 & 278 & -18 & $1 \cdot 85^{c}$ & $0.57^{b}$ & $1 \cdot 73^{\mathrm{b}}$ \\
\hline 3 & Corn oil & 9 & 336 & 271 & -19 & $0 \cdot 80^{\mathrm{a}}$ & $0.04^{a}$ & $0 \cdot 15^{2}$ \\
\hline 4 & Intact & 6 & 333 & 439 & +32 & $3 \cdot 29^{d}$ & $0.65^{b}$ & $1 \cdot 70^{\mathrm{b}}$ \\
\hline
\end{tabular}

Within columns, figures with different superscripts are significantly different $(P<0.01)$.

The completeness of hypophysectomy was judged by examining the sella turcica under a dissecting microscope at the time of autopsy, and incompletely hypophysectomized rats were excluded from the study.

The weight of the testes, ventral prostate and seminal vesicles were subjected to an analysis of variance, and individual comparisons were made by the Newman-Keuls procedure (Winer, 1962).

The changes in body weight and organ weights of the animals during the 4 weeks of the experiment are shown in Table 1 .

The smears obtained from the caput epididymidis at the time of autopsy revealed motile spermatozoa in all rats in Groups 1,2 and 4. Histological examination of epididymides showed only mature spermatozoa in the intact rats. Two of the Group-1 rats showed some immature spermatids and mature spermatozoa in the epididymal tubules; the remainder contained only mature spermatozoa. All of the Group-2 rats had immature spermatids and mature spermatozoa in the epididymal tubules. The histological appearances of the seminal vesicles and ventral prostates of rats in Groups 1 and 2 were indistinguishable from those of intact rats.

The Leydig cells of Group-1 and Group-2 rats were atrophic and similar to those of Group-3 controls in which all the seminiferous tubules were also 
atrophic and characterized primarily by spermatogonia and primary spermatocytes. The results of quantification of spermatogenesis are presented in Table 2 . The numbers of tubules counted in each group were not significantly different between various groups. Most seminiferous tubules in Group-1 rats were indistinguishable from those of intact animals; only two had any regressing tubules. In Group-2 rats, there were more regressing than normal tubules and the distribution of the latter at stages VII and VIII was bimodal.

Table 2. Effect of hypophysectomy and treatment with testosterone or DHT on the seminiferous tubules of rats

\begin{tabular}{|c|c|c|c|c|c|c|}
\hline Treatment & $\begin{array}{l}\text { Rat } \\
\text { No. }\end{array}$ & $\begin{array}{c}\text { No. of tubules } \\
\text { at stages } \\
\text { other than } \\
\text { VII or VIII }\end{array}$ & $\begin{array}{l}\text { No. of } \\
\text { regressing } \\
\text { tubules }\end{array}$ & $\begin{array}{l}\text { No. of tubules } \\
\text { at Stages } \\
\text { VII and VIII }\end{array}$ & $\begin{array}{l}\text { Total no. of } \\
\text { tubules in a testis } \\
\text { cross-section }\end{array}$ & $\begin{array}{l}\% \text { tubules } \\
\text { at Stages } \\
\text { VII and VIII }\end{array}$ \\
\hline$\underset{(\mathrm{DHT})}{\text { Group } 1}$ & $\begin{array}{r}1 \\
2 \\
3 \\
4 \\
5 \\
6 \\
7 \\
8 \\
9 \\
10\end{array}$ & $\begin{array}{l}518 \\
608 \\
536 \\
655 \\
566 \\
462 \\
664 \\
557 \\
507 \\
517\end{array}$ & $\begin{array}{r}33 \\
25 \\
0 \\
0 \\
0 \\
0 \\
0 \\
0 \\
0 \\
0\end{array}$ & $\begin{array}{r}63 \\
74 \\
144 \\
124 \\
182 \\
149 \\
180 \\
111 \\
158 \\
197\end{array}$ & $\begin{array}{l}614 \\
707 \\
680 \\
779 \\
748 \\
611 \\
844 \\
668 \\
665 \\
714\end{array}$ & $\begin{array}{l}10 \cdot 26 \\
10 \cdot 47 \\
21 \cdot 18 \\
15 \cdot 92 \\
24 \cdot 33 \\
24 \cdot 39 \\
21 \cdot 33 \\
16 \cdot 62 \\
23 \cdot 76 \\
27 \cdot 59\end{array}$ \\
\hline Mean \pm S.E. & & & & $138 \pm 14$ & $703 \pm 22$ & $19 \cdot 59 \pm 1 \cdot 90^{\mathrm{a}, \mathrm{b}}$ \\
\hline $\begin{array}{l}\text { Group 2 } \\
\text { (testosterone) }\end{array}$ & $\begin{array}{l}11 \\
12 \\
13 \\
14\end{array}$ & $\begin{array}{l}472 \\
113 \\
137 \\
608\end{array}$ & $\begin{array}{l}207 \\
593 \\
434 \\
117\end{array}$ & $\begin{array}{r}15 \\
6 \\
2 \\
4\end{array}$ & $\begin{array}{l}694 \\
712 \\
573 \\
729\end{array}$ & $\begin{array}{l}2 \cdot 16 \\
0 \cdot 84 \\
0 \cdot 35 \\
0 \cdot 55\end{array}$ \\
\hline Mean \pm S.E. & & & & $6 \pm 2$ & $677 \pm 35$ & $0.98 \pm 0.41$ \\
\hline & $\begin{array}{l}15 \\
16 \\
17 \\
18 \\
19\end{array}$ & $\begin{array}{l}452 \\
559 \\
742 \\
526 \\
539\end{array}$ & $\begin{array}{l}23 \\
38 \\
15 \\
18 \\
75\end{array}$ & $\begin{array}{r}52 \\
66 \\
120 \\
75 \\
44\end{array}$ & $\begin{array}{l}527 \\
663 \\
877 \\
619 \\
658\end{array}$ & $\begin{array}{r}9 \cdot 87 \\
9 \cdot 95 \\
13 \cdot 68 \\
12 \cdot 11 \\
6 \cdot 69\end{array}$ \\
\hline Mean \pm S.E. & & & & $71 \pm 13$ & $668 \pm 57$ & $10 \cdot 46 \pm 1 \cdot 18^{b, c}$ \\
\hline $\begin{array}{l}\text { Group } 4 \\
\text { (intact controls) }\end{array}$ & $\begin{array}{l}20 \\
21 \\
22 \\
23 \\
24 \\
25\end{array}$ & $\begin{array}{l}551 \\
496 \\
470 \\
578 \\
589 \\
309\end{array}$ & $\begin{array}{l}0 \\
0 \\
0 \\
0 \\
0 \\
0\end{array}$ & $\begin{array}{l}116 \\
131 \\
137 \\
142 \\
168 \\
103 \\
132 \pm 9\end{array}$ & $\begin{array}{l}667 \\
627 \\
607 \\
720 \\
757 \\
412 \\
631 \pm 49\end{array}$ & $\begin{array}{l}17 \cdot 39 \\
20 \cdot 89 \\
22 \cdot 57 \\
19 \cdot 72 \\
22 \cdot 19 \\
25 \cdot 00 \\
21 \cdot 29 \pm 1 \cdot 06^{\mathrm{a}, \mathrm{c}}\end{array}$ \\
\hline
\end{tabular}

Not significantly different from each other, $P>0 \cdot 7$

- Significantly different from each other, $P<0.005$.

c Significantly different from each other, $P<0.001$.

Four of the ten females placed with Group-1 males became pregnant and produced normal complements of young (average 10.6), as did four of the nine females placed with Group-2 males. The young were raised to weaning age and appeared to be normal.

The presence of regressing tubules made the method proposed by Clermont \& Harvey (1967) for the quantification of spermatogenesis inappropriate for use in this study, and the overall reduction of 20 to $40 \%$ in cell types in hormonally 
treated hypophysectomized rats claimed by these authors has not been confirmed. Matsuyama, Yokoki \& Osaga (1971), using the same method of quantification, did not find any significant difference in the numbers of cells comprising tubules at stage VII between hypophysectomized rats treated with testosterone propionate and intact controls. This may, in part, be explained by the fact that Clermont \& Harvey (1967) initiated injections of $3 \mathrm{mg}$ testosterone propionate/day on the 5th day after hypophysectomy, while Matsuyama et al. (1971), using lower dosages of the same hormone, initiated treatment 1 day after hypophysectomy. No mention of regressing tubules was made in either of the above studies.

In the present study, tubular regression was negligible and maintenance of spermatogenesis was normal in Group-1 rats, but their testicular weight was only $73 \%$, while that of the Group- 2 rats was only $56 \%$, of that of the intact controls (Table 1). It appears that the maintenance of spermatogenesis with DHT, although considerably better than with testosterone, may not be optimal.

The similarity of the weights of seminal vesicles and prostates of Group- 1 and Group-2 with those of intact animals indicates that comparable levels of androgen were reaching these target tissues. This observation agrees with the finding of Jeffcoate \& Short (1970) who claimed that testosterone and DHT were equipotent in maintaining the prostates and seminal vesicles of castrated rats. Matsuyama et al. (1971) reported significantly heavier prostates and seminal vesicles in hypophysectomized rats injected with 400,800 and $1600 \mu \mathrm{g}$ testosterone propionate. Thus, the androgenic effect on the prostate and seminal vesicles of our animals in Groups 1 and 2 was only slightly above normal. The level of circulating androgen available to the testes of these animals may, however, have been markedly lower than the physiological levels found in the testes of normal animals. The concentration of these compounds at the seminiferous tubules is affected by the rate of absorption of the steroid from the site of injection, binding to plasma proteins, conjugation and metabolism by organs other than the testes and metabolism within the testis itself. The testis has the ability to convert testosterone to DHT (Folman, Sowell \& Eik-Nes, 1972 ) and the $5 \alpha$-reduction involved is thought to be irreversible. The seminiferous tubules can further metabolize DHT to $5 \alpha$-androstan- $3 \alpha, 17 \beta$-diol, $5 \alpha$-androstan- $3 \alpha, 17 \alpha$-diol, androsterone, $5 \alpha$-androstan-3,17-dione and other unidentified substances (J. G. Sowell, Y. Folman and K. B. Eik-Nes, personal observations). Thus, the present experiment does not provide sufficient information to determine whether DHT or its metabolite(s) were responsible for maintaining spermatogenesis. It would appear that the seminiferous tubules of the testes of normal rats are exposed to much higher levels of androgens than peripheral structures, such as the prostate and seminal vesicles.

Apart from its maintenance effect on the reproductive organs, DHT has also been tested for its ability to sustain mating behaviour. Whalen \& Luttge (1971) and Feder (1971) were unable to elicit mating behaviour in castrated male rats treated with DHT. By contrast with the rats in their studies, our rats were hypophysectomized and, rather than testing the rats for mating behaviour at periodic intervals, the females were placed with the males for 1 week. The 
fact that the rats treated with DHT sired healthy young clearly indicates that, under our experimental conditions, the mating behaviour of such rats was comparable to that of testosterone-treated animals.

The work was supported in part by N.I.H. Research Contract No. 69-2097 and N.I.H. Grant No. R01-HD-08126-01.

\section{REFERENCES}

Ahmad, N., Haltmeyer, G. C. \& Eik-Nes, K. B. (1973) Maintenance of spermatogenesis in rats with intratesticular implants containing testosterone or dihydrotestosterone (DHT). Biol. Reprod. 8, 411-419.

Clikrmont, Y. \& Harvey, S. G. (1967) Effects of hormones on spermatogenesis in the rat. Ciba Fndn Colloq. Endocr. 16, 173-196.

Glermont, Y. \& Perey, B. (1957) Quantitative study of the cell population of the seminiferous tubules in immature rats. Am. 7. Anat. 100, 241-267.

FEDER, H. H. (1971) The comparative actions of testosterone propionate and $5 \alpha$-androstan-17 $\beta$-ol-3-one propionate on the reproductive behaviour, physiology and morphology of male rats. 7 . Endocr. 51, 241-252.

Folman, Y., Sowell, J. G. \& Eik-Nes, K. B. (1972) Presence and formation of $5 \alpha$-dihydrotestosterone in rat testes in vivo and in vitro. Endocrinology, 91, 702-710.

Jefrcoate, W. J. \& Short, R. V. (1970) Dihydrotestosterone in testicular tissue and its androgenic potency in vivo. F. Endocr. 48, 199-204.

Leblond, C. P. \& Clermont, Y. (1952a) Spermiogenesis of rat, mouse, hamster and guinea pig as revealed by the "periodic acid-fuchsin sulfurous acid" technique. Am. J. Anat. 90, 167-206.

Leblond, C. P. \& Clermont, Y. (1952b) Definition of the stages of the cycle of the seminiferous epithelium in the rat. Ann. N.Y. Acad. Sci. 55, 548-573.

Matsuyama, S., Yoxokı, Y. \& Osaga, A. (1971) A quantitative study of spermatogenesis in androgen treated hypophysectomized rats. Natn. Inst. Anim. Hlth Q. (Japan), 2, 46-52.

Whalen, R. E. \& LutTge, W. G. (1971) Testosterone, androstenedione, dihydrotestosterone effects on mating behaviour of male rats. Horm. E Behav. 2, 117-125.

Winer, B. J. (1962) Statistical Principles in Experimental Design. McGraw-Hill, New York. 